\title{
Inibição in Vitro do Crescimento Micelial e da Germinação de Esporos de Aspergillus Flavus Aflatoxigênico por Rizobactérias
}

Tiago Einloft (I), Flávio Veras (I), Patricia Oliveira (I), Rafael Dionello (I)

(I) UFRGS - Universidade Federal do Rio Grande do Sul (Avenida Bento Gonçalves, 7712, Porto Alegre, Rio Grande do Sul, Brasil)

\section{Resumo}

Fungos filamentosos além de importantes deterioradores de alimentos são potencialmente produtores de micotoxinas. $\mathrm{O}$ fungo Aspergillus flavus é potencialmente produtor de Aflatoxina B1, uma micotoxina carcinogênica para humanos. Atualmente têm se buscado métodos alternativos para o controle fúngico. Muitas bactérias encontradas no sistema radicular de plantas são produtoras de compostos antifúngicos naturais e representam um grande potencial para o desenvolvimento de novos conservantes. Os objetivos deste trabalho foram: Isolar diferentes bactérias do sistema radicular de plantas de milho, avaliar sua capacidade antifúngica in vitro e testar sua habilidade de inibir a germinação de conídios de A. flavus. Amostras de solo rizosférico de plantas de milho foram coletadas no município de Eldorado do Sul, RS, Brasil e analisadas através da técnica de diluição em placas. As colônias bacterianas isoladas foram testadas quanto sua capacidade antagonista e os isolados promissores foram selecionados. Foi testada a capacidade dos isolados em inibir o crescimento micelial de A. flavus utilizando a técnica de pour plate. Foi realizada a diluição de esporos em Ágar 523 e posteriormente a solidificação, a inoculação de cada isolado bacteriano em três pontos na superfície da placa. Os halos de inibição foram medidos e classificados de acordo com a escala de Bacon \& Hinton. Para avaliar a capacidade de reduzir a germinação de esporos, foram inoculados em poças presentes em lâminas de vidro, suspensões de

\section{Referência:}

Tiago Einloft (I), Flávio Veras (I), Patricia Oliveira (I), Rafael Dionello (I).Inibição in Vitro do Crescimento Micelial e da Germinação de Esporos de Aspergillus Flavus Aflatoxigênico por Rizobactérias. In: Anais do 12을 Congresso Latinoamericano de Microbiologia e Higiene de Alimentos - MICROAL 2014 [= Blucher Food Science Proceedings, num.1, vol.1]. São Paulo: Editora Blucher, 2014. 
cada isolado bacteriano e uma suspensão de esporos fúngicos. As lâminas foram incubadas por $24 \mathrm{~h}$ à $25^{\circ} \mathrm{C}$. Após, 300 esporos foram contados para cada tratamento e foi determinada a proporção de esporos germinados. Foram isoladas 688 colônias bacterianas das quais 30 isolados apresentaram atividade antifúngica. Três isolados demonstraram-se superiores aos demais, apresentando o seguinte grau de inibição à distância: RF69: +++; RP103: ++; RP242: +++. Os três isolados demonstraram inibição de 100, 95 e 98\% da germinação de conídios de A. flavus, respectivamente. Os resultados apresentados evidenciam a capacidade dos isolados selecionados em produzir metabólitos com intensa atividade antifúngica, capaz de inibir tanto o crescimento micelial quanto a germinação de esporos viáveis, representando uma potencial alternativa para o controle de fungos micotoxigênicos.

Palavras-Chave: Aflatoxina B1, Antagonismo, Aspergillus flavus, Milho, Rizobactérias

Agência de Fomento: $\mathrm{CNPq}$ 